NBER WORKING PAPER SERIES

\title{
DEFAULT, CURRENCY CRISES AND SOVEREIGN CREDIT RATINGS
}

\author{
Carmen M. Reinhart \\ Working Paper 8738 \\ http://www.nber.org/papers/w8738 \\ NATIONAL BUREAU OF ECONOMIC RESEARCH \\ 1050 Massachusetts Avenue \\ Cambridge, MA 02138 \\ January 2002
}

This paper was prepared for the New York University-University of Maryland Project The Role of Credit Rating Agencies in the International Economy. The author wishes to thank François Bourguignon, Stijn Claessens, Ricardo Hausmann, Peter Kenen and three anonymous referees for very helpful comments, Facundo Martin, Juan Trevino, and Ioannis Tokatlidis for superb research assistance and the Center for International Political Economy for financial support. This paper was written while the author was Professor at the University of Maryland. The views expressed herein are those of the author and not necessarily those of the National Bureau of Economic Research or the IMF.

(C) 2002 by Carmen M. Reinhart. All rights reserved. Short sections of text, not to exceed two paragraphs, may be quoted without explicit permission provided that full credit, including (C) notice, is given to the source. 
Default, Currency Crises and Sovereign Credit Ratings

Carmen M. Reinhart

NBER Working Paper No. 8738

January 2002

JEL No. F30, F31, F34

\begin{abstract}
$\underline{\text { ABSTRACT }}$
Sovereign credit ratings play an important role in determining the terms and the extent to which countries have access to international capital markets. In principle, there is no reason why changes in sovereign credit ratings should be expected to systematically predict a currency crisis. In practice, however, in developing countries there is a strong link between currency crises and default. About 85 percent of all the defaults in the sample are linked with currency crises. The results presented here suggest that sovereign credit ratings systematically fail to anticipate currency crises--but do considerably better predicting defaults. Downgrades usually follow the currency crisis--possibly highlighting how currency instability increases default risk.
\end{abstract}

Carmen M. Reinhart

International Monetary Fund

700 19th Street, NW

Washington, DC 20431

and NBER

Tel: 202-623-4793

Fax: 202-623-7271

Email: creinhart@imf.org

www.puaf.umd.edu/papers/reinhart.htm 


\section{Introduction}

Sovereign credit ratings play an important role in determining the terms and the extent to which countries have access to international capital markets. As more countries are added to the list of rated sovereigns, the issue of the information content of ratings becomes even more important. ${ }^{1}$ Credit ratings have been shown to have a significant impact on sovereign bond yield spreads. ${ }^{2}$ Indeed, sovereign credit ratings are supposed to serve as a summary measure of a country's likelihood of default. Hence, it is hardly surprising to find that the countries with the lowest ratings are those that are unable to borrow from international capital markets altogether and depend on official loans from multilateral institutions or from individual governments. In this cross-sectional sense, sovereign credit ratings do well in distinguishing across borrowers.

Industrial countries take international capital market access for granted. At the other end of the spectrum, many low income countries, mired with a debt overhang, have no access to international lending even under relatively favorable states of nature. ${ }^{3}$ For emerging markets (EMs), however, access to international capital markets is precarious and highly variable across time. It is for these economies that the sovereign credit ratings play their most critical role.

In principle, there is no reason why changes in sovereign credit ratings should be expected to systematically predict a currency crisis or a banking crisis. After all, industrial

${ }^{1}$ To cite a recent example, Standard and Poor's added Guatemala to the list of rated sovereigns in November 2001.

2 See, for example, Larrain, Reisen and Von Maltzan (1997), who find evidence that ratings "Granger-cause" sovereign bond yield spreads.

${ }^{3}$ Examples of favorable states of nature include both shocks that are idiosyncratic to the country--such as an increase in the terms of trade, or common shocks such as declining world interest rates. 
countries have had their share of currency crises (i.e., France and the United Kingdom in the 1992-93 Exchange Rate Mechanism crisis), banking crises (Japan, the S\&L crisis in the United States), or both simultaneously (i.e., the Nordic countries and Spain). ${ }^{4}$ In practice, however, in EMs there is a strong link between currency crises and default. ${ }^{5}$ Without the colossal bail-out packages that were put together by the international community, there is little doubt that the currency crises in Mexico, South Korea, Thailand and, more recently, Turkey would have all produced a sovereign debt default. ${ }^{6}$ Hence, if credit ratings are forward-looking and currency crises in EMs are linked to defaults, then it logically follows that currency crises should be systematically preceded by downgrades. It is this temporal (rather than cross sectional) behavior of credit ratings that I am interested in investigating.

Yet, recent anecdotal evidence does not suggest that financial crises were preceded by downgrades in credit ratings. As the chronology in Table 1 illustrates, the downgrades appear to materialize after and not before the crises in Asia. A question that arises from these recent episodes is if this failure on the part of the rating agencies to anticipate debt servicing difficulties is more generalized and systematic. Goldstein, Kaminsky, and Reinhart (2000), who examine the links between currency and banking crises and changes in sovereign credit ratings for 20 countries for Institutional Investor and Moody's, find mixed evidence on rating agencies ability to anticipate financial crises. Neither of the rating agencies predict banking crises but--they

4 For an analysis of twin crises episodes, see Kaminsky and Reinhart (1999).

${ }^{5}$ Further more, some of the indicators that are useful in predicting currency crises arealso useful to predict debt crises, see Detragiache and Spilimbergo (2001).

${ }^{6}$ Even if the government does not have much outstanding debt, history has shown that in such times governments assume private sector debt time after time. 
present some evidence that the Moody' sovereign ratings have some (very low) predictive power for currency crises.

In this paper, I cast the net wider. Depending on the rating agency, I examine the linkages between crises, default, and rating changes for anywhere between 46 to 62 countries. The analysis is also extended to include Standard and Poor's sovereign ratings and different approaches to date the currency crises.

Calvo and Reinhart (2000) have suggested that one of the reasons why EMs may fear devaluations (or large depreciations) is that these are associated with a loss of access to international credit--which is associated with severe recessions. ${ }^{7}$ To examine this issue, Section I begins by assessing the temporal links between defaults and currency crises. This section also focuses on the behavior of sovereign credit ratings in the aftermath of crises--the issue is to examine to what extent does a currency crises leads to a reassessment of sovereign default risk. In Section III, I attempt to evaluate the predictive ability of sovereign credit ratings using the approach taken in much of the literature on currency and, more recently, banking crises and estimate a family of probit models. The next section examines the descriptive statistics for the ratings along the lines of the "signals" approach and compares how these stack up to the other leading indicators that have been analyzed. This section also discusses some of the macroeconomic indicators that rating agencies focus on in their rating decisions while the concluding section discusses the implications of the findings and possible extensions of this analysis.

\footnotetext{
${ }^{7}$ They present evidence that the recessions following devaluations are deeper in EMs than in developed economies.
} 


\section{Crises, Default and its Aftermath}

In this section, I first examine the link between episodes of sovereign default and currency and banking crises. As discussed earlier, the anecdotal evidence from the recent crises episodes suggests that the downward adjustments in sovereign credit ratings came after the currency crisis was well underway. Hence, in the second part of this section, I review the evolution of credit ratings after the crises--with an emphasis on analyzing if there are distinct patterns for developed and emerging economies.

\section{Data and definitions}

My analysis covers the sovereign credit ratings issued by Moody's Investor Service and Institutional Investor (II), and Standard and Poor's. The II sample begins in 1979 and runs through 1999. For the Moody's and Standard and Poor's ratings, we have an unbalanced panel. ${ }^{8}$ For II, the ratings are an index that runs from zero (least creditworthy) to 100 (most creditworthy). The II rankings are reported twice a year and are changed frequently. For Moody's, and Standard and Poor's, which uses multiple letters to characterize a sovereign's creditworthiness, I map their letter ratings into sixteen possible categories, with sixteen corresponding to the highest rating and zero to the lowest. ${ }^{9}$ For illustrative purposes, Moody's scale is reproduced in Table 2 . The ratings may be changed at any time, hence we have the month during which any changes took place. Unlike the II rankings, rating changes are much

\footnotetext{
${ }^{8}$ An unbalanced panel, in this case, refers to the fact that we do not have the same number of observations for all the countries.

9 This approach follows the procedure adopted in Cantor and Packer (1996a and 1996b).
} 
rarer.

The country coverage of my sample for the three ratings is shown on Table 3 . With 62 countries, II constitutes the largest sample. The smallest sample is Standard and Poor's with 46 countries included; nonetheless, this is more than twice the size of the sample used in Goldstein, Kaminsky, and Reinhart (2000). ${ }^{10}$ For the exercise which examines the links across currency crises and defaults, my sample includes 59 countries and spans 1970-1999. The countries are those listed in the bottom panel of Table 3.

\section{Methodology issues}

To assess the interaction between currency and banking crises, default and sovereign credit ratings, I must first date the crises. I construct a two currency crises indices. This allows me to assess whether the links between the ratings and the crises results are sensitive to the definition of crises used. The first of these crisis indices is that used in Kaminsky and Reinhart (1999), for 20 countries--but now extended to the larger sample. The second is the crisis definition employed by Frankel and Rose (1996). ${ }^{11}$

The Kaminsky and Reinhart (1999) crisis index (KR), I, is a weighted average of the rate of change of the exchange rate, ) e/e, and of reserves, ) R/R, with weights such that the two components of the index have equal sample volatilities,

$$
\left.I=() e / e)-\left(F_{e} / F_{R}\right) *() R / R\right)
$$

10 Their sample consisted of 20 countries.

11 In an earlier version of this paper also included a modified version of Frankel and Rose, that dates "milder" crises episodes. 
where $F_{e}$ is the standard deviation of the rate of change of the exchange rate and $F_{R}$ is the standard deviation of the rate of change of reserves. Since changes in the exchange rate enter with a positive weight and changes in reserves have a negative weight attached, readings of this index that were three standard deviations or more above the mean were cataloged as crises. For countries in the sample that had hyperinflation, the construction of the index was modified. While a 100 percent devaluation may be traumatic for a country with low-to-moderate inflation, a devaluation of that magnitude is commonplace during hyperinflation. A single index for the countries that had hyperinflation episodes would miss sizable devaluations and reserve losses in the moderate inflation periods, since the historic mean is distorted by the high-inflation episode. To avoid this, I divided the sample according to whether inflation in the previous six months was higher than $150 \%$ and then constructed an index for each subsample. ${ }^{12}$ As noted in earlier studies which use the signals approach, the dates of the crises map well onto the dates obtained if one were to rely exclusively on events, such the closing of the exchange markets or a change in the exchange rate regime, to define crises.

The Frankel and Rose (FR) definition is a devaluation in a given month of 25 percent or greater--which is at least 10 percent greater than the devaluation in the preceding month. ${ }^{13} 14$ To date the default episodes, I rely on Beers and Bhatia (1999), who provide default dates

${ }^{12}$ Similar results are obtained looking at significant departures in inflation from a six-month and twelve-month moving average.

${ }^{13}$ Frankel and Rose (1996).

${ }^{14}$ The modified version of the FR index (MFR) used in my earlier paper classifies as crises a devaluation in a given month of 20 percent or greater--which is at least 5 percent greater than the devaluation in the preceding month. 
from 1824 to 1999 (I focus on the 1970-1999 subperiod), Beim and Calomiris (2001), the World Bank Debt Tables (various issues), the debt crises dates provided by Detragiache and Spilimbergo (2001) are also used. ${ }^{15}$ In some cases, these sources pinpoint the exact month in which the default was announced. Both default on foreign currency bank debt and foreign currency bond debt are included--defaults on local currency instruments are not. The sample includes default dates for both rated and unrated sovereigns.

\section{A sketch of the signals approach}

I next use the "signals" approach developed in Kaminsky and Reinhart (1999) to compare the performance of the ratings--and some of the economic indicators which rating agencies focus on--to some of the other (and better) predictors of financial crises. In a nutshell, the "signals" approach involves a set of possible outcomes is presented in the following two-by-two matrix, ${ }^{16}$

\begin{tabular}{|l|l|l|}
\hline & $\begin{array}{c}\text { Crisis occurs in the following } \\
\mathbf{2 4} \text { months }\end{array}$ & $\begin{array}{c}\text { No crisis occurs in the following } \\
\mathbf{2 4} \text { months }\end{array}$ \\
\hline Signal & A & B \\
\hline No signal & C & D \\
\hline
\end{tabular}

A perfect indicator would only have entries in cells A and D.

${ }^{15}$ Detragiache and Spilimbergo (2001) classify an observation as a debt crisis if either or both of the following conditions occur: 1) there are arrears of principal or interest on external obligations toward commercial creditors (banks or bondholders) of more than 5 percent of total commercial debt outstanding; 2) there is a rescheduling or debt restructuring agreement with commercial creditors as listed in the World Bank's Global Development Finance.

${ }^{16}$ For a more detailed description see Lizondo, Kaminsky, and Reinhart (1998) and Goldstein, Kaminsky, and Reinhart (2000). 
With this matrix I can define several useful concepts which I will use to evaluate the performance of each indicator. If one lacked any information on the performance of the indicators, it is still possible to calculate, for a given sample, the unconditional probability of crisis,

$\mathrm{P} C=(\mathrm{A}+\mathrm{C}) /(\mathrm{A}+\mathrm{B}+\mathrm{C}+\mathrm{D})$.

If an indicator sends a signal and that indicator has a reliable track record, then it can be expected that the probability of a crisis, conditional on a signal, $\mathrm{P}\left(\mathrm{C}^{*} \mathrm{~S}\right)$, is greater than the unconditional probability. Where

$\mathrm{P}\left(\mathrm{C}^{*} \mathrm{~S}\right)=\mathrm{A} /(\mathrm{A}+\mathrm{B})$

Formally,

$\mathrm{P}\left(\mathrm{C}^{*} \mathrm{~S}\right)-\mathrm{P}(\mathrm{C})>0$.

The intuition is clear, if the indicator is not "noisy" (prone to sending false alarms), then there are relatively few entries in cell B and $\mathrm{P}\left(\mathrm{C}^{*} \mathrm{~S}\right)$. 1. This is one of the criteria that I will use to rank the indicators. I can also define the noise-to-signal ratio, $\mathrm{N} / \mathrm{S}$ as, $\mathrm{N} / \mathrm{S}=[\mathrm{B} /(\mathrm{B}+\mathrm{D})] /[\mathrm{A} /(\mathrm{A}+\mathrm{C})]$

It may be the case that an indicator has relatively few false alarms in its track record. This could be the result of the indicator issuing signals relatively rarely. In this case, there is also the danger that the indicators misses the crisis altogether (it does not signal and there is a crisis). Hence, I also wish to calculate for each indicator the proportion of crises accurately called, $\mathrm{PC}=\mathrm{C} /(\mathrm{A}+\mathrm{C})$.

In the case of the credit ratings a downgrade in the 24 prior to the crisis would be considered a signal. 


\section{Currency crises and default: the linkages}

For analyzing the interaction between defaults and currency crises, the two-by-two matrix can be re-cast as follows,

\begin{tabular}{|l|l|l|}
\hline & $\begin{array}{c}\text { Currency crisis occurs in the } \\
\text { following 24 months }\end{array}$ & $\begin{array}{c}\text { No currency crisis occurs in the } \\
\text { following 24 months }\end{array}$ \\
\hline Default & A & B \\
\hline No default & C & D \\
\hline
\end{tabular}

if defaults signal currency crises or

\begin{tabular}{|l|l|l|}
\hline & $\begin{array}{c}\text { Default occurs in the following } \\
24 \text { months }\end{array}$ & \multicolumn{1}{|c|}{$\begin{array}{c}\text { No default occurs in the } \\
\text { following } 24 \text { months }\end{array}$} \\
\hline Currency crisis & A & B \\
\hline No currency crisis & C & D \\
\hline
\end{tabular}

if the converse is true. To simply look at the joint occurrence of default and currency crises without discriminating on their temporal occurrence, we would extend the 24-month window to be two-sided around the default date.

In this sample there are a total of 106 defaults and 154 currency crises, of which 135 are in emerging markets. As shown in Table 4, the unconditional probability of defaulting is 13.3 percent if the developed economies are excluded from the sample; the probability of default in this sample for the industrial economies is zero. ${ }^{17}$ The comparable unconditional probability of a

${ }^{17}$ These are the probability of new defaults not the probability of being in a default state which are larger. For example Sierra Leone was in default on its foreign currency bank debt during 1983-84 and 1986-1995. As in Beim and Calomiris (2001), we treat this as a single 
currency crisis is about 17 and does not change much when industrial countries are excluded from the sample, thereby highlighting that the key difference between developed and developing is debt problems--although, as we shall see, debt problems are very much linked to currency problems in the developing countries. The probability of having a currency crises within twenty four months of defaulting (i.e, with the crisis either before or after the default) is about 84 percent. Since defaults are somewhat rarer than currency crises, the probability of having a default within twenty four months of a currency crisis (i.e, with the default taking place either before or after the currency crash) is lower: about 58 percent for the whole sample and 66 percent for the developing country subset, which is the relevant group, as it accounts for all the default episodes in our sample. In any case, the main pont that this exercise highlights is that in developing countries (at least) there is a strong association between debt events and currency crises.

On the temporal pattern, the probability of having a currency crisis conditional on having defaulted is about 61 percent while the probability of defaulting conditional on having had a currency crisis is somewhat lower, at around 46 percent for the developing country subgroup. The inference to draw from these results is not so much that there is any obvious causal pattern-although currency crises conditional on having defaulted are more common, but rather that currency crises are more frequent and do not, in about one-half of the cases (even in developing countries), necessarily lead to default. This stylized fact, indeed, may help explain why credit ratings do not do well in predicting currency crises, an issue I take up in Section III. Of course, as discussed earlier, there are a few cases in this sample in which the currency crises would have

default episode which begins in 1983. 
precipitated a default absent a major intervention from the financial community.

\section{Sovereign credit ratings in the aftermath of crises}

Further evidence that devaluations (or large depreciations) are--more often than not followed by debt servicing difficulties can be gleaned from studying the behavior of sovereign credit ratings following such events. Tables 5 and 6 present several results from the analysis of the II and Moody's sovereign ratings, respectively. I report a variety of statistics that are meant to capture the various manifestations of the extent and the terms of access to international lending around currency crises episodes. The statistics reported include: the probability of a downgrade for various time horizons following the currency crisis, the probability of multiple downgrades, and the level of the assigned rating at the time of the crisis, and six and twelve months following that event. I also report the percent change in the ratings at several time horizons. I report the results for emerging and developed countries separately and test for differences among the two groups. Significant differences are denoted by one or more asterisks, depending on the significance level.

Turning to the II results first, as shown in the top panel of Table 5, I find no significant differences between developed countries and EMs in the probability of a downgrade (or multiple downgrades) following the currency crisis. However, this is where the similarities among the two country groups end. It is worth noting (see middle panel, Table 5) that at the time of the crisis, the average rating for the EMs is 37.6 , slightly less than half of the average score for developed countries. This, of course, suggests that even in the absence of a crisis, access to international lending is far from even for the two country groupings. Furthermore, that vast gap 
widens further in the aftermath of the devaluations associated with the currency crises. In the twelve months following the currency crisis, the magnitude of the downgrade is about five times greater for EMs than it is for developed economies. On average, EMs's sovereign rating index falls 10.8 percent in the twelve months following the currency crisis. The differences between the post-crisis downgrade for emerging and developed economies is significant at standard confidence levels.

The gulf between EMs and developed economies is even greater when a comparable exercise is performed for the Moody's ratings. As with II, the level of the ratings at the outset of the currency crisis is significantly lower for EMs--the sovereign rating level is about a third of that assigned to developed economies. Also, as the II results, the magnitude of the downgrade is far greater for EM--about 9 percent versus less than one percent for developed countries. However, as shown in Table 6, in the case of Moody's sovereign ratings, both the probability of a downgrade in the twelve months following the crisis and the probability of multiple downgrades is significantly higher for the EMs in this sample. Consistent with the findings on the interaction between defaults and currency crisis, the behavior of sovereign credit ratings in the aftermath of currency crises suggests that currency crises increase the probability of default but not necessarily that currency crises equals default.

To complement the preceding analysis, I examine whether knowing that there was a currency crisis indeed helps to predict sovereign credit rating downgrades for emerging and developed economies. For Institutional Investor, for which there is a continuous time series, I regress the six-month change in the credit rating index on the currency crisis dummy variable, which takes on the value of one when there is a crisis and zero otherwise, six months earlier. 
The method of estimation is generalized least squares, correcting for both generalized forms of heteroskedasticity and serial correlation in the residuals. For Moody's, the dependent variable is three-month changes in the rating, while the explanatory variable is the crisis dummy three months earlier. The latter specification will allow us to glean more precisely whether downgrades follow rapidly after crises take place. In the case of Moody's, the sovereign rating dependent variable is allowed to assume the value of minus one, zero, or one, depending on whether there was a downgrade, no change, or an upgrade. I estimate the parameters of interest with an ordered probit technique that allows us to correct for heteroskedastic disturbances.

The results of the estimation are summarized in Table 7 for both II and Moody's ratings. In the case of EMs, currency crises help predict downgrades, irrespective which rating index is used. For developed countries, however, there is no conclusive evidence that ratings react to currency crises in a systematic and significant way--this is perfectly consistent with the probability assessment that showed no linkages between currency crises and default--at least post-1970. For the developing countries, while the coefficients are significant at standard confidence levels, their marginal predictive contribution remains small. For example, in the case of Moody's, a currency crisis increases the likelihood of a downgrade by five percent. The results from this exercise re-enforces the view that large devaluations or depreciations in emerging markets are seen as increasing the likelihood of default--as evidenced by the markdowns in the sovereign ratings. The fact the currency crisis predictive ability is so low, would suggest that other economic fundamentals play an important role in explaining changes in sovereign credit ratings (see Cantor and Packer 1996a and 1996b, on this issue).

These results are also in line with the findings of Laraine, Reisen, and von Maltzan 
(1997), who find evidence of two-way causality between sovereign ratings and market spreads. Hence not only do international capital markets react to changes in the ratings, but the ratings systematically react (with a lag) to market conditions, as reflected in the sovereign bond yield spreads.

\section{Sovereign Credit Ratings Before the Crisis}

This analysis has shown that I) there is a strong connection between currency crises and default in emerging markets--3/4 of defaults are associated with currency crises in the months before or after the default we have also shown that ii) slightly more than half of the currency crises are not linked with a subsequent default. Nonetheless, iii) it is evident from the preceding exercise that currency crises do affect the probability of default--as EM sovereigns are systematically downgraded after currency crises. Hence, while it is critical to assess how well the ratings predict default, it is also useful (given the close connection in EMs) to assess how well sovereign credit rating changes anticipate crises.

Next I assess the predictive ability of ratings via probit estimation. The dependent variable is a currency crisis dummy and the independent variable is the 12-month change in the credit rating lagged one year. The comparable exercise is performed for the default episodes. Alternative specifications, such as the 6-month change in the credit rating lagged six months, 19 months and 24 months are also considered.

The basic premise underpinning the simple postulated model is as follows. If the credit rating agencies are using all available information on the economic "fundamentals" to form their rating decisions, then: (I) credit ratings should help predict defaults and may (or may not) predict 
currency crises--if the macroeconomic indicators on which the ratings are based have some predictive power and; (ii) the simple model should not be misspecified--that is, other indicators should not be statistically significant, since that information would already presumably reflected in the ratings themselves. Thus, the state of the macroeconomic fundamentals would be captured in a single indicator--the ratings.

Recent studies that have examined the determinants of credit ratings do provide support for the basic premise that ratings are significantly linked with selected economic fundamentals (see Lee, 1993 and Cantor and Packer, 1996a). For example, Cantor and Packer (1996a) find that per capita GDP, inflation, the level of external debt, and indicators of default history and of economic development are significant determinants of sovereign ratings.

Tables 8-10 present the results of the probit estimation, for the II , Moody's, and Standard and Poor's ratings as regressors, respectively for currency crises and defaults. The results shown in Tables 8-10 are based on the 12-month change in the ratings, 12 months before the crisis but alternative time horizons ranging from 6-month changes to 18- and 24- month changes at a variety of lag lengths produced very similar results. ${ }^{18}$ The method of estimation corrected for serial correlation and for heteroskedasticity in the residuals.

For II (Table 8) for which there are 2,195 biannual observations, the coefficients of the credit ratings have the anticipated negative sign for any of the three definitions of currency crises, that is, an upgrade reduces the probability of a crisis. However, for the two currency crisis definitions it is significant at the ten percent level. In all three cases, their marginal contribution

${ }^{18}$ A subset of these results are reported in Appendix Tables 1-3, of an earlier version of this paper while the rest are available from the author. 
to the probability of a currency crisis is very small. Furthermore, as shown in an earlier version of this paper (Reinhart, 2000), this result is not robust to other specifications. For instance, if the 6-month change in the credit rating, 6 months before the crisis is used as a regressor, none of the coefficients are statistically significant. For defaults, the II ratings are significant--but only at the ten percent confidence level.

For the Moody's ratings (Table 9) for which there are 4,774 monthly observations, the coefficients on the ratings variable are statistically insignificant for all the definitions of currency crises--in the case of the FR definition of currency crises, the coefficient has the wrong sign. Hence, for the larger 48-country sample used here the Goldstein, Kaminsky, and Reinhart (2000) results do not hold. ${ }^{19}$ Interestingly, for defaults, the II ratings are significant at the five percent confidence level. Although if one includes the potential default cases of the 1990s--these are the countries that received massive bail-out packages (without which default would have been certain), ratings are only significant at the ten percent level and very sensitive to the lag structure used.

The Standard and Poor's sample of 3,742 observations the results are line with those obtained for Moody's (Table 10). Irrespective of the crisis definition used or the specification of lag structure used none of the coefficients on the credit rating changes were statistically significant at standard confidence levels and often had the wrong sign for the crises dates--but

${ }^{19}$ For the Moody's sovereign ratings, they had found a statistically significant coefficient for their 20-country sample; while significant, though, the marginal contribution of the ratings variable was very small. 
were, indeed, much better for the default dates. ${ }^{20}$

These results would, on the surface, be at odds with the findings of Laraine, Reisen, and von Maltzan (1997), who find evidence that ratings "cause" interest rate spreads. My interpretation, however, is that, while ratings may systematically lead yield spreads (they present evidence of two-way causality)--yield spreads are poor predictors of crises but better predictors of default--this is because, as shown earlier, not all currency crises lead to default. Hence, the ratings inability to explain currency crises is not inconsistent with its ability to influence spreads. This issue will be taken up later in the paper.

\section{Credit Ratings and Macroeconomic Indicators of Crises}

Table 7 compares the performance of the ratings, and some of the economic indicators which rating agencies focus on--to some of the better predictors of financial crises. These results underscore the preceding ones, which used a different approach altogether. The table presents the basic descriptive statistics that are used in the "signals" approach to gauge an indicators" ability to anticipate crises, namely: the noise-to-signal ratio, the percent of crises accurately called, and the marginal predictive power (i.e. the difference between the conditional and unconditional probabilities). I compare II sovereign ratings to averages for the more reliable monthly and annual indicators of economic fundamentals. The basic story that emerges from Table 7 is that the credit ratings perform much worse for both currency and banking crises than do the better indicators of economic fundamentals--the individual better performing indicators are shown on

${ }^{20}$ As with Moody's the results are sensitive to the inclusion of potential default cases and to the lag structure used (i.e., longer lead of the ratings times fared much worse). 
Table 8. The noise-to-signal ratio is higher than one for both types of crises, suggesting a similar incidence of good signals and false alarms. Hence, not surprisingly, the marginal contribution to predicting a crisis is small relative to the top indicators; for banking crises the marginal contribution is nil. Furthermore, the percent of crises called is well below those of the top indicators. Indeed, the II ratings compare unfavorably with even the worst indicators. ${ }^{21}$ The results for the II ratings for larger sample considered here are even worse than those shown in Goldstein, Kaminsky, and Reinhart (2000).

\section{Why don't sovereign ratings do better predicting financial distress?}

Generally, financial crises are difficult to forecast--witness the poor performance of international interest rate spreads and currency forecasts. ${ }^{22}$ Furthermore, while the overwhelming majority of defaults in this sample are associated with currency crises the converse is not true. The results presented here offer a tentative (although partial) answer to this question. It would appear that rating agencies have tended to focus on a set of fundamentals that--when it comes to anticipating currency crises--are not the most reliable. For instance, much weight is given to debt-to-exports ratios--yet, as shown in Table 11 (memorandum item) these have tended to be poor predictors of financial stress. Little weight is attached to indicators of liquidity, currency misalignments, and asset price behavior, which as highlighted in Table 8 , are more reliable leading indicators of the kind financial stress that may lead to both currency crises and default.

${ }^{21}$ See Goldstein, Kaminsky, and Reinhart (2000) for details.

${ }^{22}$ See Lizondo, Kaminsky and Reinhart (1998) and Goldfajn and Valdés (1998), on the performance of interest rate spreads and currency forecasts, respectively. 
Detragiache and Spilimbergo (2001), for instance, present evidence that liquidity indicators, such as short-term debt and debt repayments due perform particularly well in explaining subsequent debt servicing difficulties. Openness and, as noted earlier, measures of currency overvaluation score high marks in their study.

\section{Results and Implications}

This paper has addressed the following questions: What is the interaction between currency crises and defaults? What is the behavior of credit ratings following the crises? Are there important differences in the behavior of credit ratings between developed and emerging markets? Do sovereign credit ratings systematically help predict currency crises and default? If not, why not? What, if anything, needs to change? The answers revealed by the analysis can be summarized as follows:

As to the interaction between currency crises and defaults I find that the overwhelming majority of the EM defaults (84 percent) in this sample are associated with currency crises but the converse is not true, with slightly less than $1 / 2$ of the currency crises in EMs linked to default. For the developed economies there is no evidence of any connection between currency crashes and default.

As regards the behavior of ratings after the crisis and differences between developed and emerging markets, there is evidence that sovereign credit ratings tend to be reactive--particularly when it comes to EMs. Both the probability of a downgrade and the magnitude of the downgrade are significantly higher for EMs. Taken together, these findings point to a procyclicality in the ratings but perhaps, a more instructive interpretation is that currency crises in EMs increase the 
likelihood of a default. The economic intuition is straightforward. Much of EM debt is denominated in dollars--devaluations can have significant balance sheet effects. Furthermore, most of the empirical evidence suggests devaluations are contractionary. Calvo and Reinhart, (2000), for instance, ask how the differences between developed and emerging markets in access to international capital markets influence the outcomes of a currency crisis--particularly as regards output. They present evidence that EMs are, indeed, very different from developed economies in several key dimensions. In EMs devaluations, or large depreciations for that matter, are contractionary, the adjustments in the current account and capital account are far more acute and abrupt. Hence, currency crises often become credit crises as sovereign credit ratings often collapse following the currency collapse and access to international credit is lost.

As to the ability of rating changes to anticipate financial crises, the empirical tests presented here on sovereign credit ratings and financial crises suggest that sovereign credit ratings systematically fail to anticipate currency crises--but do considerably better predicting defaults. Having said this, ratings would not have anticipated the nearly certain defaults that would have taken place in several recent crises absent large-scale bail-outs by the international community. These result appear to be robust across alternative crises definitions, model specification, and approaches.

On why are sovereign ratings such poor predictors of currency crises, I conclude that generally, financial crises are difficult to forecast--witness the poor performance of international interest rate spreads and currency forecasts. Yet, ratings do better predicting defaults--although the latter results are not as robust as regards model specification. Nonetheless, the results presented here suggest that rating agencies would do well to incorporate many indicators of 
vulnerability that have received high marks from the literature on the antecedents of currency crisis. For instance, much weight is given to debt-to-exports ratios--yet these have tended to be poor predictors of financial stress. Little weight is attached to indicators of liquidity, currency misalignments, and asset price behavior a recent study by Degatriache and Spilimbergo (2001) presents evidence that many of these indicators, which are useful in predicting currency crises, are also useful for predicting debt crises. Because another way of saying that one half of the currency crises do not end in default--is to say that one half of them do. 


\section{References}

Beim, David, O., and Charles W. Calomiris, 2001. “Emerging Financial Markets,” (New York: McGraw-Hill, Irwin)

Calvo, Guillermo A., and Carmen M. Reinhart, 2000. "Fixing for Your Life" in Collins and Rodrik (eds.) Brookings Trade Forum 2000, Policy Challenges in the Next Millenium, (Washington DC: Brookings Institution).

Cantor, Richard, and Frank Packer. 1996a. "Determinants and Impact of Sovereign Credit Ratings," Federal Reserve Bank of New York Economic Policy Review, (October), 1-15.

Cantor, Richard, and Frank Packer. 1996b. "Sovereign Risk Assessment and Agency Credit Ratings,” European Financial Management, Vol. 2, 247-56.

Detragiache, Enrica, and Antonio Spilimbergo, 2001. "Short-term Debt and Crises." Mimeograph, Washington, DC, International Monetary Fund.

Demirguç-Kunt, Asli, and Enrica Detragiache. 1998. "Banking Crises Around the World: Are There Any Common Threads." IMF Staff Papers 45, No. 1 (March), 81-109.

Frankel, Jeffrey A., and Andrew K. Rose. 1996. "Exchange Rate Crises in Emerging Markets." Journal of International Economics 41, No. 3/4 (November), 351-68.

Goldfajn, Ilan, and Rodrigo O.Valdés. 1998. “Are Currency Crises Predictable?,” European Economic Review 42 (May), 887-895.

Goldstein, Morris, Graciela L. Kaminsky and Carmen M. Reinhart, 2000. Assessing Financial Vulnerability: An Early Warning System for Emerging Markets,(Washington, DC: Institute for International Economics).

Kaminsky, Graciela L., Saul Lizondo, and Carmen M. Reinhart, 1998. "Leading Indicators of Currency Crises," IMF Staff Papers 45, No. 1 (March), 1-48.

Kaminsky, Graciela L., and Carmen M. Reinhart. 1999. "The Twin Crises: The Causes of Banking and Balance-of-Payments Problems," American Economic Review 89 No. 3, (June) 473-500.

Larraín, Guillermo, Helmut Reisen, and Julia von Maltzan. 1997. "Emerging Market Risk and Sovereign Credit Ratings," OECD Development Centre Technical Papers No. 124, (April). Paris: The Organisation for Economic Co-operation and Development.

Lee, Suk Hun. 1993. "Are the Credit Ratings Assigned by Bankers Based on the Willingness of 
Borrowers to Repay?," Journal of Development Economics 40, (April), 349-59.

Radelet, Steven, and Jeffrey Sachs. 1998. "The East Asian Financial Crisis: Diagnosis, Remedies, Prospects,"Brookings Papers on Economic Activity, 1.

Reinhart, Carmen M., 2001. "Sovereign Credit Ratings Before and After Financial Crises," mimeograph, University of Maryland, College Park. 
Table 1. Performance of Ratings Agencies Prior to Asian Crisis:

Moody's and Standard and Poor's Long Term Debt Ratings, 1996-1997

\begin{tabular}{|c|c|c|c|c|c|c|c|c|c|}
\hline & & \multicolumn{2}{|c|}{ Jan. 15, 1996} & \multicolumn{2}{|c|}{ Dec. 2, 1996} & \multicolumn{2}{|c|}{ Jun 24, 1997} & \multicolumn{2}{|c|}{ Dec. 12, 1997} \\
\hline & & Rating & Outlook & Rating & Outlook & Rating & Outlook & Rating & Outlook \\
\hline \multicolumn{10}{|c|}{ MOODY'S Foreign Currency Debt } \\
\hline Indonesia & & $\mathrm{Baa} 3$ & & Baa3 & & Baa3 & & $\mathrm{Baa} 3$ & \\
\hline Malaysia & & A1 & & $\mathrm{A} 1$ & & A1 & & A1 & \\
\hline Mexico & & $\mathrm{Ba} 2$ & & $\mathrm{Ba} 2$ & & $\mathrm{Ba} 2$ & & $\mathrm{Ba} 2$ & \\
\hline Philippines & & $\mathrm{Ba} 2$ & & $\mathrm{Ba} 2$ & & $\mathrm{Ba} 2$ & & $\mathrm{Ba} 2$ & \\
\hline $\begin{array}{l}\text { South } \\
\text { Korea }\end{array}$ & & A1 & & $\mathrm{A} 1$ & stable & & & $\mathrm{Baa} 2$ & negative \\
\hline Thailand & & $\mathrm{A} 2$ & & A2 & & $\mathrm{A} 2$ & & Baa1 & negative \\
\hline \multicolumn{8}{|c|}{ STANDARD AND POOR'S } & \multicolumn{2}{|c|}{ October 1997} \\
\hline Indonesia & $\begin{array}{l}\text { Foreign Currency } \\
\text { Debt }\end{array}$ & BBB & stable & BBB & stable & BBB & stable & BBB & negative \\
\hline & $\begin{array}{l}\text { Domestic } \\
\text { Currency Debt }\end{array}$ & & & $\mathrm{A}+$ & & $\mathrm{A}+$ & & A- & negative \\
\hline \multirow[t]{2}{*}{ Malaysia } & $\begin{array}{l}\text { Foreign Currency } \\
\text { Debt }\end{array}$ & $\mathrm{A}^{+}$ & stable & $\mathrm{A}+$ & stable & $\mathrm{A}^{+}$ & positive & $\mathrm{A}^{+}$ & negative \\
\hline & $\begin{array}{l}\text { Domestic } \\
\text { Currency Debt }\end{array}$ & $\mathrm{AA}+$ & & $\mathrm{AA}+$ & & $\mathrm{AA}+$ & & $\mathrm{AA}^{+}$ & negative \\
\hline \multirow[t]{2}{*}{ Philippines } & $\begin{array}{l}\text { Foreign Currency } \\
\text { Debt }\end{array}$ & $\mathrm{BB}$ & positive & BB & positive & $\mathrm{BB}+$ & positive & $\mathrm{BB}+$ & stable \\
\hline & $\begin{array}{l}\text { Domestic } \\
\text { Currency Debt }\end{array}$ & $\mathrm{BBB}+$ & & $\mathrm{BBB}+$ & & A- & & A- & stable \\
\hline \multirow[t]{2}{*}{$\begin{array}{l}\text { South } \\
\text { Korea }\end{array}$} & $\begin{array}{l}\text { Foreign Currency } \\
\text { Debt }\end{array}$ & AA- & stable & AA- & stable & & & & \\
\hline & $\begin{array}{l}\text { Domestic } \\
\text { Currency Debt }\end{array}$ & & & & & & & & \\
\hline \multirow[t]{2}{*}{ Thailand } & $\begin{array}{l}\text { Foreign Currency } \\
\text { Debt }\end{array}$ & A & stable & A & stable & A & stable & BBB & negative \\
\hline & $\begin{array}{l}\text { Domestic } \\
\text { Currency Debt }\end{array}$ & & & AA & & AA & & A & negative \\
\hline \multirow[t]{2}{*}{ Mexico } & $\begin{array}{l}\text { Foreign Currency } \\
\text { Debt }\end{array}$ & BB & negative & $\mathrm{BB}$ & & $\mathrm{BB}$ & & & \\
\hline & $\begin{array}{l}\text { Domestic } \\
\text { Currency Debt }\end{array}$ & $\mathrm{BBB}+$ & & $\mathrm{BBB}+$ & stable & $\mathrm{BBB}+$ & positive & & \\
\hline
\end{tabular}

Note: Rating Systems (from highest to lowest)

Moody's : Aaa, Aa1, Aa2, Aa3, A1, A2, A3, Baa1, Baa2, Baa3, Ba1, Ba2, Ba3

S\&P's : AAA, AA+, AA, AA-, A+, A, A-, BBB+, BBB, BBB-, BB+, BB, BB-

Source: Radelet and Sachs (1998). 
Table 2. Scale for Moody's Foreign Currency Debt Rating

\begin{tabular}{|c|c|}
\hline Rating Scale & Assigned Value \\
\hline $\mathrm{Aaa}$ & 16 \\
\hline $\mathrm{Aa} 1$ & 15 \\
\hline $\mathrm{Aa} 2$ & 14 \\
\hline $\mathrm{Aa} 3$ & 13 \\
\hline $\mathrm{A} 1$ & 12 \\
\hline $\mathrm{A} 2$ & 11 \\
\hline $\mathrm{A} 3$ & 10 \\
\hline $\mathrm{Baa} 1$ & 9 \\
\hline $\mathrm{Baa} 2$ & 8 \\
\hline $\mathrm{Baa} 3$ & 7 \\
\hline $\mathrm{Ba} 1$ & 6 \\
\hline $\mathrm{Ba} 2$ & 5 \\
\hline $\mathrm{Ba} 3$ & 4 \\
\hline $\mathrm{B} 1$ & 3 \\
\hline $\mathrm{B} 2$ & 2 \\
\hline $\mathrm{B} 3$ & 1 \\
\hline $\mathrm{C}$ & 0 \\
\hline
\end{tabular}

Sources: Moody's and the authors. 
Table 3. The Sample

Institutional Investors: biannual observations, 1979-1999 for 62 countries

Algeria, Argentina, Australia, Bolivia, Brazil, Canada, Chile, Colombia, Costa Rica, Czech Republic, Denmark, Dominican Republic, Ecuador, Egypt, El Salvador, Ethiopia, Finland, Ghana, Greece, Hong Kong, Hungary, India, Indonesia, Israel, Ireland, Italy, Jamaica, Japan, Jordan, Kenya, Malaysia, Mali, Mexico, Morocco, Nepal, New Zealand, Nigeria, Norway, Pakistan, Panama, Papua New Guinea, Paraguay, Peru, Philippines, Poland, Portugal, Romania, Saudi Arabia, Singapore, South Africa, South Korea, Spain, Sri Lanka, Swaziland, Sweden, Tanzania, Thailand, Turkey, United States, Uruguay, Venezuela, Zimbabwe.

Moody's Investor Service: monthly observations, unbalanced panel for 48 countries Argentina, Australia, Bolivia, Brazil, Canada, Chile, Colombia, Costa Rica, Czech Republic, Denmark, Dominican Republic, Ecuador, Egypt, El Salvador, Finland, Greece, Hong Kong, Hungary, India, Indonesia, Ireland, Israel, Italy, Japan, Jordan, Malaysia, Mexico, Morocco, New Zealand, Norway, Panama, Paraguay, Pakistan, Philippines, Poland, Portugal, Romania, Saudi Arabia, Singapore, South Africa, South Korea, Spain, Sweden, Thailand, Turkey, United States, Uruguay and, Venezuela.

Standard and Poor's: monthly observations, unbalanced panel for 46 countries

Argentina, Australia, Bolivia, Brazil, Canada, Chile, Colombia, Costa Rica, Czech Republic, Denmark, Dominican Republic, Egypt, El Salvador, Finland, Greece, Hong Kong, Hungary, India, Indonesia, Ireland, Israel, Italy, Japan, Jordan, Malaysia, Mexico, Morocco, New Zealand, Norway, Pakistan, Panama, Papua New Guinea, Paraguay, Peru, Philippines, Poland, Portugal, Romania, Singapore, South Korea, Spain, Sweden, Thailand, Turkey, United States, and, Uruguay.

Sample for the interaction between currency crisis and defaults:

59 countries, 1970-1999, 113 Defaults, 151 Currency crises

Algeria, Argentina, Bolivia, Brazil, Burkina Faso, Cameroon, Central African Republic, Chile, Colombia, Congo, Democratic Republic, Costa Rica, Cote D'Ivoire, Denmark, Dominican Republic, Ecuador, Egypt, Ethiopia, Finland, Gabon, Gambia, Ghana, Guatemala, Guinea, Guinea-Bissau, Guyana, Honduras, India, Indonesia, Israel, Jamaica, Jordan, Madagascar, Malawi, Mexico, Morocco, Nicaragua, Niger, Nigeria, Norway, Paraguay, Peru, Philippines, Romania, Sao Tome, Senegal, Sierra Leone, Spain, Suda, Sweden, Tanzania, Togo, Trinidad, Turkey, Uganda, Uruguay, Venezuela, Zambia, Zimbabwe. 
Table 4. The Twin D's: Devaluation and Default, 1970-1999

\begin{tabular}{|l|l|l|}
\hline Probability & All countries & $\begin{array}{l}\text { Developing countries } \\
\text { only }\end{array}$ \\
\hline $\begin{array}{l}\text { Unconditional probability of a default crisis occurring in } \\
\text { the next } 24 \text { months }\end{array}$ & $12.0^{1}$ & 13.3 \\
\hline $\begin{array}{l}\text { Unconditional probability of a currency crisis occurring } \\
\text { in the next } 24 \text { months }\end{array}$ & 17.3 & 16.9 \\
\hline $\begin{array}{l}\text { Probability of a currency crisis occuring within } 24 \\
\text { months before or after default }\end{array}$ & $84.0^{2}$ & 84.0 \\
\hline $\begin{array}{l}\text { Probability of a default occuring within 24 months } \\
\text { before or after the currency crisis }\end{array}$ & 57.5 & 65.7 \\
\hline $\begin{array}{l}\text { Probability of a currency crisis occurring within 24 } \\
\text { months of having defaulted }\end{array}$ & 69.3 & 69.3 \\
\hline $\begin{array}{l}\text { Probability of a default occurring within } 24 \text { months of } \\
\text { having a currency crisis }\end{array}$ & 39.4 & 46.0 \\
\hline
\end{tabular}

${ }^{1}$ The probability of default for the developed economies in our sample is zero.

${ }^{2}$ The probability for the whole sample and the developing country subset are the same owing to the fact that while the industrial countries had currency crises, none defaulted within our sample period. 
Table 5. The Probability and Magnitude of Downgrades Around Currency Crises:Institutional Investor Sovereign Credit Ratings, 1979-1999

\begin{tabular}{|c|c|c|c|}
\hline & \multicolumn{3}{|c|}{$\begin{array}{l}\text { Probability of } \\
\text { (in percent) }\end{array}$} \\
\hline $\begin{array}{l}\text { Country } \\
\text { Group }\end{array}$ & $\begin{array}{l}\text { a downgrade in six } \\
\text { months following } \\
\text { the crisis }\end{array}$ & $\begin{array}{l}\text { a downgrade in } \\
\text { twelve months } \\
\text { following the crisis }\end{array}$ & $\begin{array}{l}\text { more than one downgrade } \\
\text { in the twelve months } \\
\text { following the crisis }\end{array}$ \\
\hline Emerging & 39.0 & 79.3 & 31.7 \\
\hline Developed & 38.4 & 73.1 & 30.8 \\
\hline \multirow[t]{3}{*}{ Difference } & 0.6 & 6.2 & 0.9 \\
\hline & \multicolumn{3}{|c|}{ Index level } \\
\hline & At crisis period & Next six months & 12 months later \\
\hline Emerging & 37.6 & 36.0 & 33.5 \\
\hline Developed & 76.0 & 74.9 & 74.5 \\
\hline \multirow[t]{3}{*}{ Difference } & $-38.4^{* *}$ & $-38.9 * *$ & $-41.0 * *$ \\
\hline & \multicolumn{3}{|c|}{$\begin{array}{l}\text { Magnitude of the downgrade in } \\
\text { (percent change) }\end{array}$} \\
\hline & $\begin{array}{l}\text { six months } \\
\text { following the crisis }\end{array}$ & the next six months & $\begin{array}{l}\text { the twelve months } \\
\text { following the crisis }\end{array}$ \\
\hline Emerging & 4.3 & 6.9 & 10.9 \\
\hline Developed & 1.4 & 0.5 & 1.9 \\
\hline Difference & $2.8^{*}$ & $6.4^{* *}$ & $8.9 * *$ \\
\hline
\end{tabular}

Notes: One asterisk (*) denotes significance at the ten percent level, while two asterisks $(* *)$ denote significance at the five percent level.

Sources: Calvo and Reinhart (2000) and the author. 
Table 6. The Probability and Magnitude of Downgrades Around Currency Crises:

Moody's Sovereign Credit Ratings, 1979-1999

\begin{tabular}{|l|l|l|l|}
\hline & \multicolumn{3}{|c|}{$\begin{array}{l}\text { Probability of } \\
\text { (in percent) }\end{array}$} \\
\hline $\begin{array}{l}\text { Country } \\
\text { Group }\end{array}$ & $\begin{array}{l}\text { a downgrade in six } \\
\text { months following } \\
\text { the crisis }\end{array}$ & $\begin{array}{l}\text { a downgrade in } \\
\text { twelve months } \\
\text { following the crisis }\end{array}$ & $\begin{array}{l}\text { more than one downgrade } \\
\text { in the twelve months } \\
\text { following the crisis }\end{array}$ \\
\hline Emerging & 20.0 & 26.7 & 6.7 \\
\hline Developed & 10.0 & 10.0 & 0.0 \\
\hline Difference & $10.0^{* *}$ & $16.7^{* *}$ & $6.7 *$ \\
\hline & & \multicolumn{3}{|c|}{ Index level } \\
\hline Emerging & 4.9 & 4.5 & 4.3 \\
\hline Developed & 15.0 & 14.9 & 14.9 \\
\hline Difference & $-10.1^{* *}$ & $-10.4^{* *}$ & $-10.6^{* *}$ \\
\hline & \multicolumn{3}{|l|}{ Magnitude of the downgrade in } \\
\hline Emerging & 8.2 & $4.4^{* *}$ & $\begin{array}{l}\text { (percent change) } \\
\text { the next six months } \\
\text { following the crisis }\end{array}$ \\
\hline Difference & $7.5^{* *}$ & 4.4 & 12.2 \\
\hline & six months & 0.0 & 0.7 \\
\hline
\end{tabular}

Notes: One asterisk $(*)$ denotes significance at the ten percent level, while two asterisks $(* *)$ denote significance at the five percent level.

Sources: Calvo and Reinhart (2000) and the author. 
Table 7. Credit Ratings Following Currency Crises: Developed and Emerging Markets

\begin{tabular}{|c|c|c|c|}
\hline $\begin{array}{l}\text { Dependent variable: Institutional } \\
\text { Investor six-month changes in sovereign }\end{array}$ & \multicolumn{3}{|c|}{$\begin{array}{l}\text { Estimation method: } \\
\text { OLS with robust standard errors }\end{array}$} \\
\hline $\begin{array}{l}\text { Independent variable } \\
\text { is a currency crisis } \\
\text { dummy } \\
\end{array}$ & $\begin{array}{c}\text { Coefficient } \\
\text { (1) } \\
\end{array}$ & $\begin{array}{l}\text { Standard } \\
\text { error } \\
(2) \\
\end{array}$ & $\begin{array}{l}R^{2} \\
(4) \\
\end{array}$ \\
\hline Developed & -0.007 & 0.023 & 0.01 \\
\hline Emerging & $-0.08^{* *}$ & 0.011 & 0.07 \\
\hline $\begin{array}{l}\text { Dependent variable: Moody's three- } \\
\text { month changes in sovereign rating }\end{array}$ & \multicolumn{2}{|c|}{$\begin{array}{l}\text { Estimation method: } \\
\text { Ordered probit }\end{array}$} & \\
\hline $\begin{array}{c}\text { Independent variable } \\
\text { is a currency crisis } \\
\text { dummy } \\
\end{array}$ & $\begin{array}{c}\text { Coefficient } \\
\text { (1) } \\
\end{array}$ & $\begin{array}{l}\text { Standard } \\
\text { error } \\
(2) \\
\end{array}$ & $\begin{array}{c}\text { Pseudo } R^{2} \\
(4) \\
\end{array}$ \\
\hline Developed & -0.08 & 0.76 & 0.000 \\
\hline Emerging & $-0.31^{* *}$ & 0.11 & 0.060 \\
\hline
\end{tabular}

Note: An asterisk $(*)$ denotes difference is significant at the ten percent level, while two asterisks denote significant differences at the five percent level. 
Table 8. Do Changes in Sovereign Credit Ratings Predict Currency Crises or Default?

Probit estimation with robust standard errors

Institutional Investor, 2,195 observations

\begin{tabular}{|l|l|l|l|l|}
\hline \multicolumn{5}{|c|}{ Currency Crisis } \\
\hline $\begin{array}{l}\text { Dependent Variable: } \\
\text { Crisis Dummy }\end{array}$ & $\begin{array}{c}\text { Coefficient } \\
\mathbf{( 1 )}\end{array}$ & $\begin{array}{l}\text { Standard } \\
\text { Error } \\
\mathbf{( 2 )}\end{array}$ & $\begin{array}{l}\text { Significance } \\
\text { Level } \\
\mathbf{( 3 )}\end{array}$ & $\begin{array}{l}\text { Pseudo R }^{2} \\
\mathbf{( 4 )}\end{array}$ \\
\hline $\begin{array}{l}\text { Kaminsky and Reinhart } \\
\text { Definition }\end{array}$ & -0.435 & 0.540 & 0.072 & 0.005 \\
\hline $\begin{array}{l}\text { Frankel and Rose } \\
\text { Definition }\end{array}$ & -0.288 & 0.015 & 0.059 & 0.007 \\
\hline \multicolumn{5}{|c|}{ Defaults } \\
\hline Defaults & -0.214 & 0.015 & 0.063 & 0.011 \\
\hline $\begin{array}{l}\text { Defaults and potential } \\
\text { defaults }\end{array}$ & -0.161 & 0.021 & 0.141 & 0.008 \\
\hline
\end{tabular}

Notes: The independent variable is the 12-month change in the sovereign credit rating one year earlier. 
Table 9. Do Changes in Sovereign Credit Ratings Predict Currency Crises or Default?

Probit estimation with robust standard errors

Moody's, 4,774 observations

\begin{tabular}{|l|l|l|l|l|}
\hline \multicolumn{5}{|c|}{ Currency Crisis } \\
\hline $\begin{array}{l}\text { Dependent Variable: } \\
\text { Crisis Dummy }\end{array}$ & $\begin{array}{c}\text { Coefficient } \\
\text { (1) }\end{array}$ & $\begin{array}{l}\text { Standard } \\
\text { Error } \\
\mathbf{( 2 )}\end{array}$ & $\begin{array}{l}\text { Significance } \\
\text { Level } \\
\mathbf{( 3 )}\end{array}$ & $\begin{array}{l}\text { Pseudo R }^{\mathbf{2}} \\
\mathbf{( 4 )}\end{array}$ \\
\hline $\begin{array}{l}\text { Kaminsky and Reinhart } \\
\text { Definition }\end{array}$ & -0.217 & 0.761 & 0.412 & 0.001 \\
\hline $\begin{array}{l}\text { Frankel and Rose } \\
\text { Definition }\end{array}$ & 0.014 & 1.582 & 0.975 & 0.000 \\
\hline \multicolumn{5}{|c|}{ Defaults } \\
\hline Defaults & -0.197 & 0.102 & 0.048 & 0.010 \\
\hline $\begin{array}{l}\text { Defaults and potential } \\
\text { defaults }\end{array}$ & -0.204 & 0.180 & 0.099 & 0.007 \\
\hline
\end{tabular}

Notes: The independent variable is the 12-month change in the sovereign credit rating one year earlier. 
Table 10. Do Changes in Sovereign Credit Ratings Predict Currency Crises or Defaults in Emerging Markets?

Probit estimation with robust standard errors

Standard and Poor's, 3,742 observations

\begin{tabular}{|c|c|c|c|c|}
\hline \multicolumn{5}{|c|}{ Currency Crisis } \\
\hline $\begin{array}{l}\text { Dependent Variable: } \\
\text { Crisis Dummy }\end{array}$ & $\begin{array}{c}\text { Coefficient } \\
\text { (1) }\end{array}$ & $\begin{array}{l}\text { Standard } \\
\text { Error } \\
\quad(2)\end{array}$ & $\begin{array}{l}\text { Significance } \\
\text { Level } \\
\text { (3) }\end{array}$ & $\begin{array}{r}\text { Pseudo } R^{2} \\
\text { (4) }\end{array}$ \\
\hline $\begin{array}{l}\text { Kaminsky and Reinhart } \\
\text { Definition }\end{array}$ & -0.08 & 0.091 & 0.772 & 0.001 \\
\hline $\begin{array}{l}\text { Frankel and Rose } \\
\text { Definition }\end{array}$ & -0.014 & 0.076 & 0.721 & 0.001 \\
\hline \multicolumn{5}{|c|}{ Defaults } \\
\hline Defaults & -0.120 & 0.076 & 0.054 & 0.011 \\
\hline $\begin{array}{l}\text { Defaults and potential } \\
\text { defaults }\end{array}$ & -0.356 & 0.170 & 0.117 & 0.007 \\
\hline
\end{tabular}

Notes: The independent variable is the 12-month change in the sovereign credit rating one year earlier. 
Table 11 Institutional Investor sovereign ratings and the fundamentals

\begin{tabular}{|c|c|c|c|}
\hline $\begin{array}{l}\text { Type of crisis and } \\
\text { indicator }\end{array}$ & $\begin{array}{l}\text { Noise-to- } \\
\text { signal } \\
\text { (1) }\end{array}$ & $\begin{array}{l}\text { Percent of } \\
\text { crises } \\
\text { accurately } \\
\text { called } \\
\text { (2) }\end{array}$ & $\begin{array}{c}\text { Difference between } \\
\text { conditional and } \\
\text { unconditional } \\
\text { probability } \\
\text { (3) }\end{array}$ \\
\hline \multicolumn{4}{|l|}{ Currency crisis: } \\
\hline $\begin{array}{l}\text { Institutional Investor } \\
\text { sovereign rating }\end{array}$ & 1.07 & 29 & 5.2 \\
\hline $\begin{array}{l}\text { Average of the top } 5 \\
\text { monthly indicators }\end{array}$ & 0.45 & 70 & 19.1 \\
\hline $\begin{array}{l}\text { Average of the top } 3 \\
\text { annual indicators }\end{array}$ & 0.49 & 36 & 15.4 \\
\hline $\begin{array}{l}\text { Memorandum item: } \\
\text { Debt-to-exports ratio }\end{array}$ & 0.91 & 53 & 6.1 \\
\hline \multicolumn{4}{|l|}{ Banking crisis: } \\
\hline $\begin{array}{l}\text { Institutional Investor } \\
\text { sovereign rating }\end{array}$ & 1.62 & 22 & 0.9 \\
\hline $\begin{array}{l}\text { Average of the top } 5 \\
\text { monthly indicators }\end{array}$ & 0.50 & 72 & 9.1 \\
\hline $\begin{array}{c}\text { Average of the top } 3 \\
\text { annual indicators }\end{array}$ & 0.41 & 44 & 16.3 \\
\hline $\begin{array}{l}\text { Memorandum item: } \\
\text { Debt-to-exports ratio }\end{array}$ & 1.04 & 56 & 0.9 \\
\hline
\end{tabular}

Sources: The author and Goldstein, Kaminsky and Reinhart (2000). 